\title{
EFEKTIVITAS PEMBELAJARAN KOOPERATIF TIPE NHT (NUMBERED HEADS TOGETHER) DENGAN MEDIA VISUAL TERHADAP HASIL BELAJAR SISWA PADAMATERI ORGANISASI KEHIDUPAN DI KELAS VII SMP REHOBOTH
}

\author{
Marti $^{1)}$, Syamswisna ${ }^{2)}$, Ruqiah Ganda Putri Panjaitan ${ }^{2)}$ \\ ${ }^{1)}$ Mahasiswa Prodi P. Biologi, FKIP, Universitas Tanjungpura Pontianak \\ ${ }^{2)}$ Program Studi P. Biologi, FKIP, Universitas Tanjungpura Pontianak \\ ruqiah_gpp@gmail.com
}

\begin{abstract}
This research is aimed to determine the effectivity of cooperative learning model through Numbered Heads Together (NHT) by visual media on students' achievement in material life organization of VII grade SMP Rehoboth. The research is quasi experimental design, with nonequivalen control group design. The research samples are VIIa and VIIb grade. The technique of data collecting is by using random sampling. The average score of the students' achievement that has been teach by using Numbered Heads Together (NHT) of cooperative learning model with visual media is 14,89 as higher than the conventional model of 11,29. The $t$-test in standard $5 \%$ shows $t_{\text {count }}=5,023$ bigger than its comparation to $t_{\text {table }}=$ 1,679, it means there is a significant difference in the post-test result. The counting of effect size is 1,27 it includes high, so the concluded that Numbered Heads Together (NHT) of cooperative learning model with visual media gave 39,80\% of contribution on students' achievement.
\end{abstract}

Key words : Numbered heads together, visual media.

Proses pembelajaran merupakan proses komunikasi, yaitu penyampaian pesan dari sumber pesan melalui saluran/ media tertentu ke penerima pesan (Sadiman, 2009). Pesan yang disampaikan guru kepada siswa berupa materi pelajaran dengan menggunakan model dan media sebagai alat bantu dalam proses pembelajaran. Keberhasilan siswa dalam proses belajar dapat terlihat dari hasil belajar.

Berdasarkan hasil diskusi tanggal 19 Juli 2010 dengan guru biologi kelas VII SMP Rehoboth tahun ajaran 2009/2010, rata-rata hasil belajar biologi pada materi organisasi kehidupan (47) lebih rendah dibandingkan dengan materi ciri-ciri makhluk hidup (62), ekosistem (60), dan pencemaran lingkungan (54). Penyebab rendahnya hasil belajar siswa adalah guru selalu menggunakan metode ceramah dan kurangnya penggunaan media dalam proses pembelajaran. Lebih lanjut, observasi tanggal 19 Juli 2010 di kelas VII SMP Rehoboth menunjukkan dalam proses pembelajaran guru memberikan catatan kepada siswa dan menjelaskan poin-poin penting, memberi siswa kesempatan untuk bertanya, selanjutnya siswa diminta untuk mengerjakan LKS. Lembar Kerja siswa (LKS) tersebut dikerjakan oleh siswa secara individu. Dalam proses pembelajaran seperti ini terlihat bahwa pembelajaran yang dilakukan guru kurang mengaktifkan siswa dalam belajar, karena dalam proses 
pembelajaran siswa tidak terlibat langsung sehingga siswa merasa jenuh.

Salah satu solusi untuk mengatasi rendahnya keaktifan dan hasil belajar adalah dengan pembelajaran kooperatif. Isjoni (2007) menyatakan bahwa dalam pembelajaran kooperatif siswa terlibat aktif, sehingga memberikan damapak positif terhadap prestasi belajar. Dalam pembelajaran kooperatif dikenal berbagai tipe, salah satunya adalah pembelajaran kooperatif tipe Numbered Heads Together (NHT). Menurut Nur (dalam Azizah, 2007), "Tipe Numbered Heads Together (NHT) pada dasarnya merupakan sebuah varian diskusi kelompok, dengan ciri khasnya adalah guru hanya menunjuk salah satu siswa yang dapat mewakili kelompoknya tanpa memberi tahu dahulu siapa yang akan mewakili kelompoknya".

Materi organisasi kehidupan merupakan materi yang mencakup sel, jaringan, organ, dan sistem organ. Dalam proses pembelajaran, salah satu tujuan yang ingin dicapai adalah membedakan struktur sel hewan dan sel tumbuhan. Secara umum, keseluruhan isi dari materi ini merupakan konsep-konsep yang sifatnya abstrak, oleh karena itu dalam penyajian materi ini tidak cukup hanya disajikan dalam bentuk ceramah dan hafalan tetapi diperlukan suatu media untuk memvisualisasikan materi yang sifatnya abstrak. Djamarah dan Zain (2006) mengatakan bahwa, kehadiran VIIB. Sampel dalam penelitian ini adalah siswa kelas VIIA yang berjumlah 28 siswa dan kelas VIIB berjumlah 27 siswa. Penentuan kelas media sangat membantu siswa dalam memahami konsep tertentu, yang tidak atau kurang mampu dijelaskan dengan bahasa. Salah satu media yang menjadi alternatif utama adalah media visual. Menurut Munadi (2008), "Media visual adalah media yang hanya melibatkan indra penglihatan".

Berdasarkan latar belakang di atas, maka dilakukan penelitian untuk mengetahui hasil belajar siswa dan efektivitas melalui pembelajaran kooperatif tipe Numbered Heads Together (NHT) dengan media visual pada materi organisasi kehidupan di kelas VII SMP Rehoboth. Dalam penelitian ini, diharapkan penggunaan media visual berupa model sel, anatomi daun, sel saraf, anatomi batang yang terbuat dari styrofoam, tumbuhan ceplukan, dan torso dapat membantu siswa untuk melihat langsung suatu objek yang sifatnya abstrak seperti struktur sel, struktur jaringan, organ dan sistem organ.

\section{Metode}

Penelitian ini merupakan penelitian eksperimen semu, dengan rancangan nonequivalent control group design. Menurut Sugiyono (2009), rancangan nonequivalent control group design adalah pola rancangan penelitian dengan sampel yang tidak dipilih secara randomisasi. Populasi dalam penelitian ini adalah siswa kelas VII SMP Rehoboth yang terdiri dari VIIA

dan

kontrol dan kelas eksperimen dilakukan dengan cara pengundian, sehingga ditetapkan kelas VIIA 
sebagai kelas eksperimen dan kelas VIIB sebagai kelas kontrol.

Instrumen yang digunakan dalam penelitian ini adalah soal pretest dan post-test sebanyak 20 soal dengan bentuk pilihan ganda. Soal pre-tes diberikan untuk melihat kemampuan awal siswa, sedangkan soal post-tes untuk melihat pengaruh pembelajaran terhadap hasil belajar siswa. Selanjutnya untuk mengetahui apakah data skor pre-test dan data skor post-test normal atau tidak normal digunakan uji chi-kuadrat. Jika hasil uji chi-kuadrat menunjukkan kedua data terdistribusi normal maka dilanjutkan dengan uji homogenitas. Jika kedua varians homogen dilanjutkan dengan uji-t. Menurut Glass (dalam Sutrisno, 2001), besarnya efektivitas model pembelajaran kooperatif tipe Numbered Heads Together (NHT) dengan media visual diperoleh dari perhitungan effect size dengan rumus:

$$
E S=\frac{\bar{X}_{e}-\bar{X}_{k}}{S D_{k}}
$$

Keterangan :

$$
\begin{array}{ll}
E S & =\text { effect size } \\
\bar{X}_{e} & =\text { rata-rata perubahan skor } \\
& \text { kelompok eksperimen } \\
\bar{X}_{k} & =\text { rata-rata perubahan skor } \\
& \begin{array}{l}
\text { kelompok kontrol } \\
S D_{k}
\end{array} \\
& =\text { standar deviasi kelompok } \\
& \text { kontrol }
\end{array}
$$

\section{Hasil dan Pembahasan}

Hasil belajar menurut Abdurrahman (dalam Jihad dan Haris, 2009) adalah kemampuan yang diperoleh anak setelah melalui kegiatan belajar. Hasil belajar dalam penelitian ini adalah tingkat keberhasilan siswa pada materi organisasi kehidupan yang diajarkan menggunakan pembelajaran kooperatif tipe Numbered Heads Together (NHT) dengan media visual (Tabel 1).

Tabel 1: Hasil Belajar Siswa pada Materi Organisasi Kehidupan di SMP Rehoboth Bengkayang Tahun Ajaran 2010/2011.

\begin{tabular}{|lccccc|}
\hline \multicolumn{1}{|c}{ Kelas } & $\bar{X}$ & SD & \multicolumn{2}{c|}{ Harga $\chi^{2}$} & Keterangan \\
\cline { 3 - 5 } & & & Hitung & Tabel & \\
\hline Eksperimen & 14,89 & 2,51 & 6,80 & 7,82 & Normal \\
\hline Kontrol & 11,29 & 2,89 & 4,11 & 7,82 & Normal \\
\hline Keterangan: & & & & \\
$\bar{x}$ & $=$ rata-rata skor & & & \\
SD & $=$ standar deviasi & & & \\
Skor total & $=$ 20 & & & \\
$\chi^{2}$ & $=$ chi- kuadrat & & & \\
\end{tabular}

Berdasarkan Tabel 1, data dari kelas eksperimen dan kelas kontrol berdistribusi normal sehingga dilakukan uji homogenitas dan diperoleh $\quad \mathrm{F}_{\text {hitung(1,33) }}<\mathrm{F}_{\text {tabel(1,95) }}$ artinya kedua data homogen. Dari uji $\mathrm{t}$ diperoleh $\mathrm{t}$ hitung $(5,02)>\mathrm{t}_{\text {tabel }}(1,68)$ artinya hipotesis alternatif Ho di tolak dan $\mathrm{Ha}$ diterima. Hal ini menunjukkan terdapat perbedaan yang signifikan antara hasil belajar siswa pada kelas eksperimen yang 
diajar menggunakan model pembelajaran kooperatif tipe Numbered Heads Together (NHT) dengan media visual dan kelas kontrol yang diajar menggunakan model pembelajaran konvensional (ceramah). Lebih lanjut, berdasarkan perhitungan effect size (ES) diperoleh efektifitas model pembelajaran kooperatif tipe Numbered Heads Together (NHT) dengan media visual sebesar 1,27 dan termasuk ke dalam kategori tinggi. Kontribusi yang diberikan model pembelajaran kooperatif tipe Numbered Heads Together (NHT) dengan media visual terhadap peningkatan hasil belajar siswa pada materi organisasi kehidupan sebesar 39,80\%.

Berdasarkan tabel 1 rata-rata skor hasil belajar siswa pada kelas eksperimen lebih tinggi dibandingkan dengan kelas kontrol. Tingginya hasil belajar siswa kelas eksperimen juga diikuti dengan persentase tingkat ketuntasan hasil belajar siswa. Kriteria Ketuntasan Minimal (KKM) yang ditetapkan oleh SMP Rehoboth tahun ajaran 2010/2011 adalah 60 . Pada kelas eksperimen dari 28 siswa ada 26 siswa yang mencapai ketuntasan hasil belajar dengan persentase ketuntasan sebesar 92,86\%. Sedangkan pada kelas kontrol dari 27 siswa hanya 14 siswa yang mencapai ketuntasan hasil belajar dengan persentase ketuntasan sebesar 51,85\%. Hal ini disebabkan penggunaan model pembelajaran kooperatif tipe NHT. Model pembelajaran kooperatif tipe NHT merupakan variasi diskusi kelompok (Nur dalam Azizah, 2007). Dengan adanya belajar berkelompok ini siswa terlibat aktif dalam proses pembelajaran, keterlibatan siswa secara aktif pada proses pembelajaran mempengaruhi hasil belajar siswa, sehingga pembelajaran tersebut memiliki makna. Sesuai dengan pendapat Dewey (dalam Jihad dan Haris, 2009) belajar bermakna akan tercipta jika siswa terlibat aktif dalam proses pembelajaran, sehingga siswa akan lebih banyak mengingat materi yang diajarkan oleh guru.

Berdasarkan data skor posttest siswa pada kelas eksperimen dan kelas kontrol yang terdapat perbedaan dari tingkat ketuntasan hasil belajar, maka untuk mempertegas perbedaan hasil belajar siswa dilanjutkan dengan menghitung persentase rata-rata kemampuan siswa menjawab benar soal post-test per tujuan pembelajaran (Gambar 1).

Gambar 1 menunjukkan bahwa persentase kemampuan siswa yang menjawab benar soal post-test pada kelas eksperimen lebih tinggi dari kelas kontrol. Hal ini menunjukkan bahwa model pembelajaran kooperatif tipe NHT dengan media visual pada kelas eksperimen membantu siswa dalam memahami materi pelajaran.

Pada tujuan pembelajaran kedua, ketiga, kelima, keenam, kedelapan, kesembilan, kesepuluh, dan kesebelas dapat dilihat bahwa persentase siswa yang menjawab benar di kelas eksperimen lebih tinggi. Tingginya persentase kemampuan siswa yang menjawab benar soal post-test yang berkaitan dengan gambar pada kelas eksperimen disebabkan dari pengunaan model pembelajaran kooperatif tipe NHT dengan media visual. 


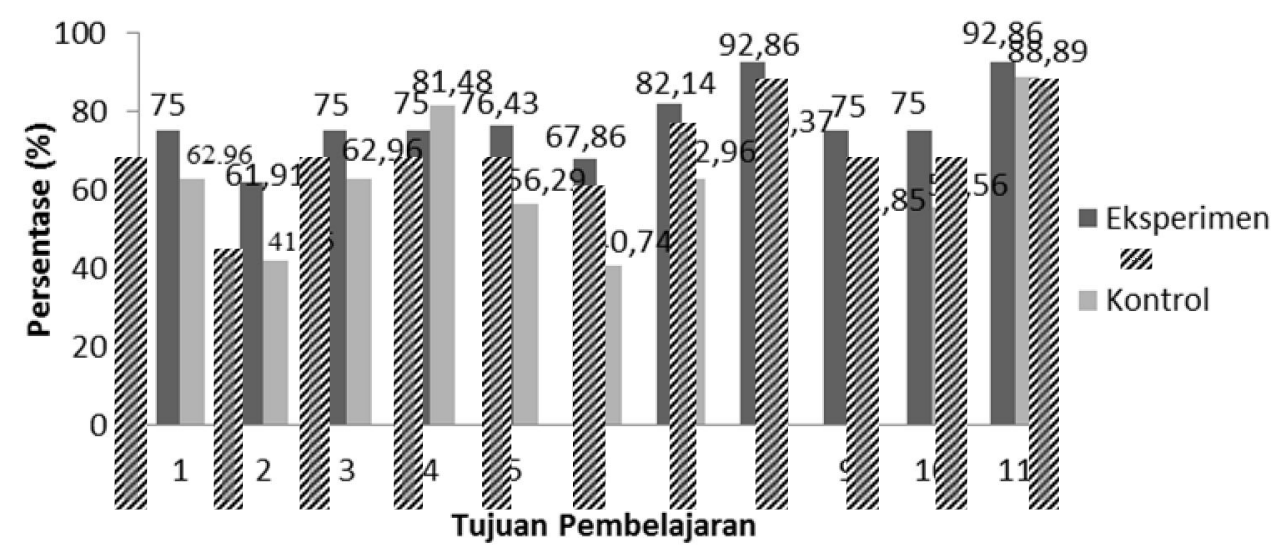

Gambar 1: Persentase Jumlah Siswa yang Menjawab Benar pada Kelas Eksperimen dan Kelas Kontrol per Tujuan Pembelajaran pada Materi Organisasi Kehidupan di SMP Rehoboth Tahun Ajaran 2010/2011.

Keterangan:

Tujuan pembelajaran:

1. Siswa dapat menjelaskan pengertian sel dengan benar.

2. Siswa dapat mengidentifikasi struktur dan fungsi sel dengan benar.

3. Siswa dapat membedakan sel hewan dan sel tumbuhan.

4. Siswa dapat menjelaskan pengertian jaringan dengan benar.

5. Siswa dapat mengidentifikasi berbagai jenis jaringan pada hewan dan tumbuhan.

6. Siswa dapat menjelaskan fungsi jaringan pada hewan dan tumbuhan.

7. Siswa dapat menjelaskan pengertian organ dengan benar.

8. Siswa dapat mengidentifikasi organ pada manusia

9. Siswa dapat mengidentifikasi organ-organ pada tumbuhan beserta fungsinya.
10. Siswa dapat menyebutkan organ-organ penyusun sistem organ pada manusia.

11. Siswa dapat menentukan urutan terbentuknya sistem organisasi kehidupan.

Berdasarkan pendapat Putriana (2009) pembelajaran tipe NHT memberikan kesempatan kepada siswa untuk saling membagikan ide-ide dan mempertimbangkan jawaban yang paling tepat, serta dapat mendorong siswa untuk dapat meningkatkan semangat kerja sama. Lebih lanjut, media visual juga dapat membantu siswa memahami materi yang bersifat abstrak. Sedangkan rendahnya persentase siswa pada kelas kontrol karena penyampaian materi didominasi oleh metode ceramah dan tidak ada media yang digunakan. Sesuai dengan pendapat Djamarah dan Zain (2006), bahwa ketidak jelasan materi yang disampaikan dapat dibantu dengan menghadirkan Selain itu, menurut Hidayati (2008) penggunaan media dalam proses 
pembelajaran dapat meningkatkan pemahaman dan mampu mengaktifkan siswa dalam proses pembelajaran. Sejalan dengan hasil penelitian ini, hasil penelitian Nisayuniar (2008) menyatakan menunjukkan bahwa penerapan model pembelajaran kooperatif tipe Numbered Heads Together (NHT) dengan menggunakan media visual berupa torso pada materi sistem pencernaan memberikan pengaruh positif terhadap hasil belajar siswa di kelas VIII SMP Negeri 13 Makasar.

Persentase siswa yang menjawab benar pada tujuan pembelajaran kesatu dan ketujuh yang lebih tinggi di kelas eksperimen lebih tinggi dari kelas kontrol. Soal posttest tersebut berkaitan dengan kemampuan menjelaskan. Tingginya kemampuan siswa dalam menyelesaikan soal ini dikarenakan penggunaan model pembelajaran kooperatif tipe Numbered Heads Together (NHT) dengan media visual yang dapat membantu siswa dalam memahami materi seperti penjelasan tentang sel, dan organ siswa di bantu dengan media powerpoint. Dengan adanya bantuan media powerpoint dalam proses pembelajaran siswa dapat melihat secara langsung apa yang dijelaskan oleh guru serta siswa dapat secara langsung mencatat poinpoin penting. Sedangkan pada kelas kontrol siswa hanya mendengarkan penjelasan dari guru. Sebagaimana yang dinyatakan Djamarah dan Zain (2006) bahwa penjelasan yang dominasi oleh metode ceramah bila selalu digunakan dan terlalu lama akan membuat siswa bosan.

Dalam penelitian ini, walaupun 10 tujuan pembelajaran pada kelas eksperimen menunjukkan persentase siswa yang menjawab benar soal post-test lebih tinggi dari kelas kontrol namun pada tujuan pembelajaran keempat persentase siswa yang menjawab benar pada kelas eksperimen lebih rendah dibandingkan kelas kontrol. Soal yang adalah pengertian jaringan. Penyampaian tentang pengertian jaringan di kelas dengan menggunakan powerpoint sedangkan pada kelas kontrol guru menjelaskan dengan mendikte. Di kelas eksperimen, pada saat guru menjelaskan pengertian jaringan dengan powepoint siswa banyak tidak serius dan akhirnya banyak siswa yang tidak mencatat. Sebaliknya pada kelas kontrol, siswa belajar dengan serius dan mencatat apa yang dibacakan oleh guru. Diasumsikan bahwa penyebab rendahnya kemampuan siswa menjawab benar pada kelas eksperimen karena kurangnya perhatian ssiwa dalam mendengar penjelasan guru.

\section{Simpulan dan Saran}

Dari hasil penelitian ini dapat disimpulkan bahwa pembelajaran model kooperatif tipe Numbered Heads Together (NHT) dengan media visual dapat meningkatkan hasil belajar siswa dengan rata-rata skor post-test sebesar 14,96. Penerapan model pembelajaran kooperatif tipe Numbered Heads Together (NHT) dengan media visual juga efektif dalam meningkatkan hasil belajar siswa dengan memberikan kontribusi sebesar 39,80\% terhadap hasil belajar siswa.

\section{Daftar Pustaka}


Efektivitas Pembelajaran Kooperatif 27

Azizah, N. 2007. Keefektifan Penggunaan Model Pembelajaran Kooperatif Tipe NHT (Numbered- HeadsTogether) dengan Pemanfaatan LKS (Lembar Kerja Siswa) pada Pokok Bahasan Bangun Ruan Sisi Datar (Kubus dan Balok) Siswa Kelas VIII Semester 2 SMP N 6 Semarang Tahun Pelajaran 2006/2007. (Online)(http://digilib.unnes.ac.i d/gsdl/collect/skripsi/archives/H ASH01d8/e207de66.dir/doc.pdf. diakses 7 Juli 2010) (Halaman 2).

Djamarah, S. B \& Aswan, Z. 2006. Strategi Belajar Mengajar. Jakarta: PT. Rineka Cipta (Halaman 2).

Hidayati, A.Z. 2008. Penggunaan Media Tiga Dimensi dalam Pelaksanaan Kurikulum 2006 untuk Meningkatkan Hasil Belajar Biologi pada Siswa Kelas XI Ia SMA Muhammadiyah 1 Surakarta Tahun Ajaran 2007/2008.

(Online)(http://etd.eprints.ums.a c.id/747/1/A420040099.pdf,diak ses 17 Januari 2012) (Halaman $6)$.

Isjoni. 2007. Cooperative Learning. Bandung: Alfabeta (Halaman 2).

Jihad, A. \& Haris, A. 2009. Evaluasi Pembelajaran. Yogyakarta: Multi Pressindo (Halaman 3).

Munadi, Y. 2008. Media Pembelajaran (Sebuah Pendekatan Baru). Jakarta:
Gaung Persada Press (Halaman 2).

Nisayuniar. 2008. Pengaruh Media Visual dalam Pembelajaran Kooperatif Tipe Number Heads Together (NHT) Terhadap Hasil Belajar Biologi Siswa Kelas VIII SMP 13 Makassar. (Online).(http://one.indoskripsi. com/judul-skripsi/pendidikanbiologi/pengaruh media-visualdalam-pembelajarankooperatiftipe-number-heads-togethernhtterhadap-, diakses 6 Juli 2010) (Halaman 6).

Putriana, M.S. 2009. Peningkatan Proses dan Hasil Belajar Biologi pada Pokok Materi Ekosistem dengan Model Pembelajaran Kooperatif Tipe NHT (Numbered Heads Together) pada Siswa Kelas VII SMP Negeri 2 Sidoharjo Tahun Pelajaran 2008/2009. (Online),(http://etd.eprints.ums. ac.id/4264/1/A420050024.pdf, diakses 18 Januari 2012) (Halaman 6).

Sadiman, A.S., Rahardjo, R., Haryono, A. \& Rahardjto. 2009. Media Pendidikan Pengertian, Pengembangan, dan Pemanfaatan. Jakarta: Raja Grafindo persada (Halaman 1).

Sugiyono. 2009. Metode Penelitian Kuantitatif, Kualitatif dan $R$ \& $D$. Bandung: Alfabeta (Halaman 2).

Sutrisno, L. 2001. Kofirmasi Data. (Online).(http://www.scribd.co $\underline{\mathrm{m} / \text { documentdownloads/459600 }}$ $\underline{8 \text { ?secretpassword }=\& \text { extension }=}$ 
28 Jurnal Pendidikan Matematika dan IPA Vol. 5. No. 2. Juli 2014: 21-27

ppt, diakses 9 Juli 2010) (Halaman 3). 